Food, Dairy and Home Economic Research

\title{
EVALUATION OF NUTRITIONAL STATUS OF PRE-SCHOOL CHILDREN IN SHARKIA GOVERNORATE
}

\author{
Soad M. Abd El-Latife ${ }^{1 *}$, Sohir E. El-Saiedy ${ }^{1}$ and S.A. Hafez ${ }^{2}$ \\ 1. Food Sci. Dept., Fac. Agric., Zagazig Univ., Egypt \\ 2. Food Technol. Res. Inst., Agric. Res. Cent., Egypt
}

Received: 21/11/2017; Accepted: 24/12/2017

\begin{abstract}
The aim of the study was to evaluate the nutritional status of children attending preschools located in Sharkia Governorate, Egypt. The study was carried out in 2008until 2010. The studied samples were pre-school children (boys and girls) aged between 4-6 years. They were selected from the kinder garden, in Sharkia Government. The total randomly pre-school children samples were 200 children divided to 100 children from K.G in rural areas sorted as 46 boys and 54 girls. 100 children were from urban areas sorted as 47 boys and 53 girls. Information about home food intake was collected by parents, on the same days, the kind and quantity of food eaten by the child in the preschool were noted. The results revealed that the nutritional status of more than half of the children was appropriate, however, one out of five children exhibited overweight in rural area, while one out of four children exhibited overweight or obesity in urban area. The analyzed menus revealed that most nutrients were oversupplied in relation to the requirements. The intake of total protein, animal proteins, copper, as well as vitamins A, B2, and B6, exceeded the recommended levels more than twice. Other B-group vitamins, vitamin C, phosphorus, magnesium, and sodium were supplied in a considerable surplus too. On the other hand, more than a half of the children received diets with insufficient amounts of calcium, potassium, and cholesterol in rural and urban areas (male and female).The dietary deficiencies may have a negative impact on the physical and mental development of the children and may increase a risk of diseases in their future adult life.
\end{abstract}

Key words: Nutritional status, pre-school children, dietary deficiencies, obesity.

\section{INTRODUCTION}

Children are the country's biggest human investment for development. Quality of life of pre-school children, by all standards continues to be poor more so in rural areas and urban slums (Saluja et al., 2011). Hence evaluation of the nutritional status of the children is imperative as it is an important index of the national investment in the development of its future manpower. Nutritional status during school age is a major determinant of nutritional and health status in adult life (Shaikh et al., 2016).

Children demonstrate particular susceptibility to nutritional deficiencies during growth (Kozlowska-

\footnotetext{
* Corresponding author: Tel. : +201223818209

E-mail address:dr.soadmostafa28@gmail.com
}

Wojciechowska and Makarewicz-Wujec, 2005). Excessive intake of energy and nutrients, however, can also have a negative impact on the health (Szponar et al., 2003). Dietary patterns imposed on children can significantly affect not only their physical and mental development, but also form the eating habits that persist over their entire adult life (Gawęcki et al., 2005). Proper nutrition of children, therefore, is crucial both for their optimal growth during the childhood and in terms of their health when they grow up (O'dea, 2003). The nutrition of children at the age 4-6 heavily depends on whether they attend a pre-school care institution and, if so, on the quality of meals offered there. The latter often raises serious concerns (Pudlo et al., 2000; 
Gawęcki et al., 2005). The authors who study child nutrition in pre-schools usually evaluate the energy and nutritional value of the meals offered to children in their pre-schools. Rare are the reports, however, that deal with the entire daily ration actually consumed by pre-school children, including food eaten at home (Sadowsk et al., 2010).

Nutrition is one of a number of factors that may influence a child's development as well as genetic, socio-economic, environmental and behavioral factors. There is much interest in the role of nutrition in a child's physical development but understanding the relationship between nutrition and mental development and performance in children is equally important in terms of their attainment and productivity in both school and in later life (Abdel-Rahman et al., 2017).

The aim of the study was to evaluate the nutritional status and nutrition manner of children attending pre-schools, in the some rural and urban areas of Sharkia Governorate, Egypt.

\section{MATERIALS AND METHODS}

\section{Study Groups}

The studied samples were pre-school children boys and girls aged between 4-6 years. They were selected from the kinder garden, in Sharkia Governorate. The total randomly pre-school children samples were 200 divided as follows: 100 children from K.G in rural areas sorted as 46 boys and 54 girls. 100 children from urban areas sorted as 47 boys and 53 girls. The samples were taken from different kinder garden as following:

Urban areas assimilate Zagazig city and Hehia city:

Al-Nasseria kinder garden in Zagazig city, Zagazig university kinder garden, Hehia kinder garden.

Rural areas assimilate El-Asaid and Ekrash village in Diarb Negm city:

Ekrash kinder garden. El-Asaid kinder garden. Al-Fouad kinder garden. Data were collected during the school years 2008 until 2010.

\section{Tools of the Study}

\section{Social-economic survey}

It included the following aspects:

\section{Data related to the sample itself}

Gender, Age, Kind of kinder garden, place of living, the order of the child in his family.

\section{Social case of the parents}

Parent's education, Parent's occupation, Mother's information source.

\section{Income of family features}

Size of the family, Income source.

\section{Anthropometric Measurements}

The Anthropometric Measurements included weight and length. Accurate measures are needed for an assessment of the nutritional status of a child relative to his or her past growth and to provide some indications of growth of the samples can be irregular and still consider normal due to differences in the rate of growth and maturation that can occur among children at the same chronological age the techniques suggested by WHO (1995).

\section{Body Weight (Wt.)}

The children weight was obtained by using a kilogram scale ranging from 1-150 kilogram to the nearest $1.0 \mathrm{~kg}$ with minimum of the underclothing and without shoes. Scale was at (0) to be sure that it was balance then.

\section{Length}

Height was taken to the nearest $0.5 \mathrm{Cm}$ using a centimeter ruler ranging from $0-200 \mathrm{Cm}$. The subjects stood on a flat floor without shoes; looking straight up. The head had been hold comfortably erect. The arms were hanging at the sides in natural manner. Shoulders perpendicular to the trunk. Straightened the legs and brings the footboard up.

\section{Nutritional assessment}

The Nutritional assessment includes dietary intake and analyzing the dietary survey food preferences pattern practices. (Look Annex 1-2). 


\section{Dietary intake}

The Dietary intake included the following aspects: Twenty four- hour recall method and Food frequency.

A predestined dietary form was used to determine food intake by using 24 - hour recall. It gave an idea about pattern of food consumption in rural and urban communities.

Each student subject was asked to recall everything that he or she consumed, including food obtained away from home, quantities eaten. Then calculated the nutritive value of the intake using the Food Composition Tables for Egypt. These actual values were compared with the Dietary Reference Intake (DRI) of these age ranges (Nutrition, 2004). Interview was done with some of the pre- scholar's mothers to confirm the dietary information and more knowledge about ingredients of the common dishes, to help in visualizing quantities. Boys and girls were provided with common measuring cups, spoons and plates.

Protein, calories, iron and calcium of the dietary survey were analyses according to (DRI) for this age (Nutrition, 2004).

\section{Statistical Analysis}

The collected data were coded and entered in a data base file, then after completed data entry, the data were transferred to the SPSS version 20 program (Dominiek and Derrick, 2001).

\section{RESULTS AND DISCUSSION}

\section{Distribution of Pre-School Children Characteristics in Rural and Urban in Sharkia Governorate}

Distribution of pre-school children characteristics in rural and urban in Sharkia Governorate are presented in Table 1. It can be seen that $46 \%$ of children were boys in rural area as ratio $23 \%$ while the girls were 54 as $27 \%$. In urban area there were 47 of children were boys as $23.5 \%$, while the girls were 53 as $26.5 \%$.
Results in Table 1 shows the distribution of children sample according to age in rural and urban. It can be seen that 21 of children aged between 4- 4.5 years as a ratio of $10.5 \%$, thirty eight of children as ratio $19 \%$ aged between 4.5 5.5 years and 41 of children as a ratio of $20.5 \%$ aged between 5.5- 6.0 years in rural area, while in urban area were 30 of children were under the age of 4- 4.5 years as a ratio of $15.0 \%$, forty nine of children as a ratio of $24.5 \%$ aged between $4.5-5.5$ years and 21 of children as a ratio of $10.5 \%$ aged between $5.5-6.0$ years.

Table 2 showed the distribution of pre-school children length and weight in rural and urban areas in Sharkia Governorate, the majority of children length in rural area were $(33.5 \%)$ un normal, while the minority were $(2.0 \%)$ normal, while $(14.5 \%)$ were up normal. In urban area the majority of children length were $(35.0 \%)$ un normal, the minority were $(2.0 \%)$ normal, while $(13.0 \%)$ were up normal, as shown there, was no significant differences between different groups of children according to length in rural and urban areas. These differences may be due to height or total body length is influenced by heredity apart from nutritional and other environment factors Nanda (2000) and Hanumantha et al. (1994) reported that tribal pre-school children belonging to three ecological zones of Madhya Pradesh were shorter to NCHS children but were comparable to rural Madhya Pradesh children. Dolla et al. (2005) observed that the mean height increased significantly with increase in age, these results are in agreement with Grover et al. (2009).

Also, results in Table 2 show that the majority of children weight in rural area were $(30.5 \%)$ un normal, the minority were $(9.5 \%)$ normal, while $(10.0 \%)$ were up normal. In urban area,the majority of children weight were $(33.0 \%)$ un normal, the minority were $(4.5 \%)$ normal, while $(12.5 \%)$ were up normal. These may be due to height or total body length is influenced by heredity apart from nutritional and other environment factors Hanumantha et al. (1994). These results are in agreement with Grover et al. (2009). As shown there were no significant differences between groups of children according to weight in rural and urban areas. 
Table 1. Distribution of pre-school children characteristics in rural and urban in Sharkia Governorate

\begin{tabular}{|c|c|c|c|c|c|c|}
\hline \multirow[t]{3}{*}{ Item } & \multicolumn{4}{|c|}{ Place of living } & \multicolumn{2}{|c|}{ Total } \\
\hline & \multicolumn{2}{|c|}{ Rural } & \multicolumn{2}{|c|}{ Urban } & \multirow[b]{2}{*}{ No. } & \multirow[b]{2}{*}{$(\%)$} \\
\hline & No. & $(\%)$ & No. & $(\%)$ & & \\
\hline \multicolumn{7}{|c|}{ Gender of children } \\
\hline - Mal & 46 & 23.0 & 47 & 23.5 & 93 & 46.5 \\
\hline - Female & 54 & 27.0 & 53 & 26.5 & 107 & 53.5 \\
\hline Total & 100 & 50.0 & 100 & 50.0 & 200 & 100 \\
\hline \multicolumn{7}{|c|}{ Age of children (year) } \\
\hline$-4-4.5$ & 21 & 10.5 & 30 & 15.0 & 51 & 25.5 \\
\hline$-4.5-5.5$ & 38 & 19.0 & 49 & 24.5 & 87 & 42.5 \\
\hline$-5.5-6.0$ & 41 & 20.5 & 21 & 10.5 & 62 & 31.5 \\
\hline Total & 100 & 50.0 & 100 & 50.0 & 200 & 100 \\
\hline
\end{tabular}

Table 2. Distribution of pre-school children length and weight in rural and urban areas in Sharkia Governorate

\begin{tabular}{|c|c|c|c|c|c|c|c|c|c|}
\hline \multirow[t]{3}{*}{ Item } & \multicolumn{4}{|c|}{ Place of living } & \multirow{2}{*}{\multicolumn{2}{|c|}{ Total }} & \multirow[t]{3}{*}{$\overline{X^{2}}$} & \multirow[t]{3}{*}{ df } & \multirow[t]{3}{*}{$\mathbf{p}$} \\
\hline & \multicolumn{2}{|c|}{ Rural } & \multicolumn{2}{|c|}{ Urban } & & & & & \\
\hline & No. & $(\%)$ & No. & $(\%)$ & No. & $(\%)$ & & & \\
\hline \multicolumn{10}{|l|}{ Length (cm) } \\
\hline - 80-111 cm $\leq$ (un normal) & 67 & 33.5 & 70 & 35 & 137 & 68.5 & \multirow{4}{*}{0.229} & \multirow{4}{*}{2} & \multirow{4}{*}{0.892} \\
\hline$-112 \mathrm{~cm} \geq$ (normal) & 4 & 2.0 & 4 & 2.0 & 8 & 4.0 & & & \\
\hline$-113-123 \mathrm{~cm} \geq$ (up normal) & 29 & 14.5 & 26 & 13.0 & 55 & 27.5 & & & \\
\hline Total & 100 & 50 & 100 & 50 & 200 & 100 & & & \\
\hline \multicolumn{10}{|l|}{ Weight(kg) } \\
\hline - 10-19.9 kg $\leq$ (un normal) & 61 & 30.5 & 66 & 33 & 127 & 63.5 & \multirow{4}{*}{4.324} & \multirow{4}{*}{2} & \multirow{3}{*}{0.115} \\
\hline$-20 \mathrm{~kg} \geq$ (normal) & 19 & 9.5 & 9 & 4.5 & 28 & 14.0 & & & \\
\hline$-21-29 \mathrm{~kg} \geq$ (up normal) & 20 & 10.0 & 25 & 12.5 & 45 & 22.5 & & & \\
\hline Total & 100 & 50 & 100 & 50 & 200 & 100 & & & \\
\hline
\end{tabular}


Distribution of Consumption of Meals at Home, by Examined Pre-School Children

Degree of eating breakfast and essential three meals in rural and urban is shown in Table 3 there were no significant differences between them in both areas. There were $90 \%$ of children eating breakfast in rural area, $2 \%$ sometimes, $6 \%$ rarely and $2 \%$ don't eating breakfast. While in urban area, $83 \%$ of children eating breakfast, $13 \%$ sometimes, $1 \%$ rarely and $3 \%$ don't eating breakfast.

In rural area $76 \%$ of children eating three meals, $22 \%$ sometimes, $2 \%$ rarely and $0 \%$ don't eating three meals. In urban area $71 \%$ of children eating three meals, $26 \%$ sometimes, $1 \%$ rarely and $2 \%$ don't eating three meals.

The high percentage of children with overweight or obesity may be a consequence of the fact that parents often repeat at home the meals that the child has already eaten at school Table 3. Serving the breakfast before leaving home can by of advantage to the child; however, a second midday meal during the day may easily result in overfeeding, leading in consequence to excessive weight or obesity. Breakfast eaten at home prevents hypoglycemia and enhances resistance to cold, which in turn is important for prevention of infections. Pre-school age is a good time to easily shape behavior patterns and habits in a growing child, also those related to diet and nutrition which become habitual and persist throughout the adult life (Friedrich and Rukojć, 2001).

\section{Distribution of Consumption of Supper Meals, by Examined Pre-School Children}

Degree of preparing completely meals and child eating between the meals in rural and urban is shown in Table 4, there were high significant differences between them in both areas. There were $35.5 \%$ of children rarely preparing completely meals in rural area and $14.5 \%$ don't preparing completely meals. While in urban area $29.5 \%$ of children rarely preparing completely meals and $20.5 \%$ don't preparing completely meals.

In rural area there were $42.5 \%$ of children eating between the meals, $6 \%$ sometimes, $1.5 \%$ rarely and $0 \%$ don't eat. While in urban area there were $27.0 \%$ of children eating between the meals, $17.5 \%$ sometimes, $2.0 \%$ rarely and $3.5 \%$ don't eat.
Overweight and obesity were also correlated with between-meals eating, which was observed in nearly all the children (Table 4). The snacks eaten by the children usually comprised sweets, fruit, as well as sweet dairy products. The presence of sweets in the diet was reflected by a large portion of sucrose in the daily energy ration (Sadowsk et al., 2010).

\section{Content of Energy and Main Nutrition Components in Daily Food Rations of Examined Pre-school Children in Rural and Urban Areas}

Daily food rations of the children were composed of the meals served at the pre-school and those eaten at home. The mean total intake of most nutritional components in the diet considerably exceeded the standards (Table 5). The consumed amounts of total protein, animal proteins, copper, iron, vitamins A, B2, and B6 exceeded the recommended levels more than twice. Other B-group vitamins, vitamin C, phosphorus, magnesium, and sodium were supplied in a considerable surplus too in rural and urban areas (boys and girls).

The high level of protein supply is particularly dangerous. Despite their importance for the growth and development of the child, protein should be not consumed in such high levels. An excess may lead to acidification of the system and can burden the liver and kidneys, forced to excrete additional levels of nitrogen compounds (Weatherholtz et al., 1969).

Sodium is another dietary component supplied to the studied children in excess. Sodium increases water retention in the system and represents one of the factors underlying adult-age arterial hypertension. It should be stressed that dietary habits formed during childhood persist throughout the entire life (Gronowska-Senger, 2007). Hence, exposure to salt food in childhood may result in a preference of the taste of salt observed at a later age.

There were deficiencies in the diet of the studied pre-school children, daily supply of cholesterol, potassium, and calcium did not mean the recommended levels in rural and urban areas (boys and girls,Table 5). Similar, calcium deficiencies in the diets were found by Charzewska and Weker (2006), who studied daily rations of 4-years-old children in various regions of Poland. 
Table 3. Distribution of children sample according to degree of eating breakfast and essential three meals in rural and urban

\begin{tabular}{|c|c|c|c|c|c|c|c|}
\hline \multirow[t]{3}{*}{ Item } & \multicolumn{4}{|c|}{ Place of living } & \multirow[t]{3}{*}{$\mathbf{X}^{2}$} & \multirow[t]{3}{*}{ df } & \multirow[t]{3}{*}{$\mathbf{p}$} \\
\hline & \multicolumn{2}{|c|}{ Rural } & \multicolumn{2}{|c|}{ Urban } & & & \\
\hline & No. & $(\%)$ & No. & $(\%)$ & & & \\
\hline \multicolumn{8}{|c|}{ Number and percentage of eating breakfast } \\
\hline Yes & 90 & 45.0 & 83 & 41.5 & & & \\
\hline Sometimes & 2 & 1.0 & 13 & 6.5 & \multirow{4}{*}{3.396} & \multirow{4}{*}{3} & 0325 \\
\hline Rarely & 6 & 3.0 & 1 & 0.5 & & & \\
\hline No. & 2 & 1.0 & 3 & 1.5 & & & \\
\hline Total & 100 & 50 & 100 & 50 & & & \\
\hline \multicolumn{8}{|c|}{ Number and percentage of eating essential three meals } \\
\hline Yes & 76 & 38.0 & 71 & 35.5 & & & \\
\hline Sometimes & 22 & 11.0 & 26 & 13.0 & \multirow[t]{4}{*}{2.837} & \multirow[t]{4}{*}{1} & \multirow[t]{4}{*}{0.075} \\
\hline Rarely & 2 & 1.0 & 1 & 0.5 & & & \\
\hline No. & 0 & 0 & 2 & 1.0 & & & \\
\hline Total & 100 & 50 & 100 & 50 & & & \\
\hline
\end{tabular}

Table 4. Distribution of children sample according to degree of preparing completely meals and child eating between the meals in rural and urban

\begin{tabular}{|c|c|c|c|c|c|c|c|}
\hline \multirow[t]{3}{*}{ Item } & \multicolumn{4}{|c|}{ Place of living } & \multirow{3}{*}{\multicolumn{2}{|c|}{$X^{2} \quad$ df }} & \multirow[t]{3}{*}{$\mathbf{p}$} \\
\hline & \multicolumn{2}{|c|}{ Rural } & \multicolumn{2}{|c|}{ Urban } & & & \\
\hline & No. & $\overline{(\%)}$ & No. & $(\%)$ & & & \\
\hline \multicolumn{8}{|c|}{ Number and percentage of preparing completely meals } \\
\hline Rarely & 71 & 35.5 & 59 & 29.5 & \multirow{2}{*}{\multicolumn{2}{|c|}{$3.165 \quad 1$}} & \multirow{2}{*}{0.075} \\
\hline No & 29 & 14.5 & 41 & 20.5 & & & \\
\hline Total & 100 & 50 & 100 & 50 & & & \\
\hline \multicolumn{8}{|c|}{ Number and percentage of child eatin between the meals } \\
\hline Yes & 85 & 42.5 & 54 & 27.0 & & & \\
\hline Sometimes & 12 & 6.0 & 35 & 17.5 & 25.312 & 3 & $0.000^{* * *}$ \\
\hline Rarely & 3 & 1.5 & 4 & 2.0 & & & \\
\hline No & 0 & 0 & 7 & 3.5 & & & \\
\hline Total & 100 & 50 & 100 & 50 & & & \\
\hline
\end{tabular}


Table 5. Dietary intake of energy and main nutrition components in daily food rations of examined pre-school children in rural and urban

\begin{tabular}{|c|c|c|c|c|c|}
\hline \multirow[t]{2}{*}{ Item/day } & \multirow{2}{*}{$\begin{array}{c}\text { Rural girls } \\
\text { Mean } \pm \text { SD }\end{array}$} & \multirow{2}{*}{$\begin{array}{l}\text { Urban girls } \\
\text { Mean } \pm \text { SD }\end{array}$} & \multirow{2}{*}{$\begin{array}{c}\text { Rural boys } \\
\text { Mean } \pm \text { SD }\end{array}$} & \multirow{2}{*}{$\begin{array}{l}\text { Urban boys } \\
\text { Mean } \pm \text { SD }\end{array}$} & \multirow{2}{*}{$\begin{array}{c}\text { Norm } \\
\text { DRI }\end{array}$} \\
\hline & & & & & \\
\hline Water, l/day & $7.44 \pm 0.213$ & $5.48 \pm 0.195$ & $7.92 \pm 0.257$ & $5.82 \pm 0.171$ & 19 \\
\hline Calories, kcal & $1595.33 \pm 362.01$ & $1357.88 \pm 402.94$ & $1597.87 \pm 431.46$ & $1419.08 \pm 415.09$ & 1400 \\
\hline Protein a, $g$ & $32.88 \pm 20.37$ & $29.52 \pm 18.76$ & $31.06 \pm 25.44$ & $33.78 \pm 18.35$ & 14.0 \\
\hline Protein $\mathbf{p}, \mathbf{g}$ & $30.12 \pm 12.11$ & $22.57 \pm 9.72$ & $28.95 \pm 12.02$ & $22.12 \pm 8.51$ & 7.0 \\
\hline Total protein, $\mathrm{g}$ & $63.01 \pm 22.38$ & $52.13 \pm 23.81$ & $60.01 \pm 30.62$ & $55.92 \pm 22.83$ & 21.0 \\
\hline Fat a, $g$ & $15.69 \pm 13.35$ & $26.22 \pm 16.23$ & $16.25 \pm 14.11$ & $24.31 \pm 18.15$ & 15.0 \\
\hline Fat $p, g$ & $29.93 \pm 15.56$ & $23.81 \pm 24.54$ & $29.66 \pm 13.66$ & $26.13 \pm 18.16$ & 35.0 \\
\hline Total fat & $45.63 \pm 14.87$ & $50.04 \pm 25.69$ & $45.89 \pm 19.61$ & $50.43 \pm 28.10$ & 50.0 \\
\hline Carb, $g$ & $233.67 \pm 65.13$ & $173.54 \pm 68.68$ & $225.75 \pm 61.99$ & $186.51 \pm 54.05$ & 130 \\
\hline Fiber, g/ d & $11.96 \pm 5.51$ & $6.4 \pm 7.81$ & $11.01 \pm 6.05$ & $5.82 \pm 5.87$ & 25 \\
\hline Ash, $\mathrm{g}$ & $7.80 \pm 2.37$ & $7.85 \pm 3.96$ & $7.22 \pm 3.09$ & $6.73 \pm 3.06$ & - \\
\hline Calcium, mg & $518.42 \pm 177.16$ & $727.60 \pm 363.90$ & $523.25 \pm 272.43$ & $554.84 \pm 180.57$ & 700 \\
\hline Phosphorus, mg & $916.51 \pm 242.33$ & $844.74 \pm 480.59$ & $937.03 \pm 374.51$ & $934.80 \pm 377.23$ & 500 \\
\hline Iron a, mg & $5.46 \pm 3.58$ & $4.72 \pm 3.07$ & $5.63 \pm 5.23$ & $5.85 \pm 5.32$ & - \\
\hline Iron p, mg & $13.65 \pm 7.13$ & $5.56 \pm 1.88$ & $12.75 \pm 8.57$ & $6.59 \pm 3.25$ & - \\
\hline Total iron & $19.10 \pm 7.44$ & $10.27 \pm 3.04$ & $18.38 \pm 10.00$ & $12.43 \pm 6.33$ & 10.00 \\
\hline Sodium, mg & $1853.56 \pm 619.00$ & $1606.40 \pm 777.10$ & $1825.73 \pm 415.18$ & $1800.10 \pm 797.54$ & 1000 \\
\hline Potassium, mg & $2335.93 \pm 623.57$ & 1557.67594 .43 & $2339.36 \pm 786.25$ & $1774.98 \pm 548.73$ & 3100 \\
\hline Zinc, mg & $6.57 \pm 1.94$ & $6.55 \pm 3.75$ & $6.54 \pm 2.70$ & $6.36 \pm 3.27$ & 5.00 \\
\hline Magnesium, mg & $285.43 \pm 75.44$ & $215.78 \pm 136.16$ & $288.85 \pm 110.14$ & $221.91 \pm 148.31$ & 130 \\
\hline Vitamin $A, \mu g$ & $625.23 \pm 637.73$ & $240.50 \pm 148.15$ & $205.84 \pm 154.07$ & $574.76 \pm 1667.20$ & 450 \\
\hline Vitamin C, mg & $180.74 \pm 203.74$ & $44.05 \pm 37.96$ & $98.76 \pm 66.45$ & $130.33 \pm 200.18$ & 50.0 \\
\hline Vitamin $D, \mu g$ & $2.41 \pm 4.92$ & $3.26 \pm 4.34$ & $1.91 \pm 3.71$ & $1.81 \pm 1.32$ & 10 \\
\hline Vitamin E, mg & $19.69 \pm 12.54$ & $12.26 \pm 8.72$ & $21.08 \pm 22.43$ & $10.70 \pm 7.56$ & 6.00 \\
\hline Vitamin B1, mg & $.77 \pm .25$ & $.63 \pm .19$ & $.85 \pm .26$ & $.60 \pm .20$ & 10.5 \\
\hline Vitamin B2, mg & $1.27 \pm .36$ & $.94 \pm .38$ & $1.18 \pm .53$ & $1.02 \pm .61$ & 0.0 \\
\hline Niacin, mg & $9.85 \pm 3.72$ & $6.62 \pm 2.53$ & $9.62 \pm 3.42$ & $8.33 \pm 3.84$ & 0.0 \\
\hline Vitamin B6, mg & $1.66 \pm .79$ & $.70 \pm .33$ & $1.57 \pm 1.00$ & $.86 \pm .38$ & 0.0 \\
\hline Vitamin B12, mg & $3.38 \pm 2.03$ & $2.36 \pm 1.88$ & $2.87 \pm 2.39$ & $2.90 \pm 2.09$ & 1.0 \\
\hline Folate & $229.51 \pm 122.93$ & $135.33 \pm 78.80$ & $216.43 \pm 96.48$ & $153.30 \pm 68.22$ & 160 \\
\hline Cholesterol, mg & $254.92 \pm 161.83$ & $243.77 \pm 138.63$ & $191.78 \pm 172.21$ & $258.48 \pm 181.51$ & 300 \\
\hline
\end{tabular}


Calcium deficiency during an intensive growth of the skeletal system may lead to rickets as well as to attaining a low final weight of the bone tissue, which in turn may result in early osteoporosis, osteopenia or an increased risk of fractures at an older age (Oltarzewski $\boldsymbol{e t}$ al., 2003). These disorders are also provoked by an improper calcium-to-phosphorus ratio, observed in the studied diets, as well as the excessive intake of sodium (Table 5), since sodium enhances urinary excretion of calcium (Kleeman et al., 1964), especially at a lowcalcium diet (Nordin and Policy, 1987).

Potassium deficiencies in the diet of the studied children probably results from a low consumption of wholegrain cereal products and vegetables, which are among the food items usually disliked by children (Kolarzyk et al., 2000). Low level of potassium leads to acidification of the organism hampers the neuromuscular response and slows down cellular oxidation, (Ciborowska and Rudnicka, 2007) In terms of hypertension, low potassium can have a negative impact as an excess of sodium (WHO, 1999)

It should be noted that even small iron deficiencies lead to reduced physical fitness and disorders in the immunological system. In children, they also degrade the cognitive abilities and hamper learning processes due to impaired the metabolism of neurotransmitters and oxygen transport and accumulation in the central nervous system (Walter, 1994). Heavier and long-lasting iron deficiencies lead to hemoglobin synthesis disorders, anemia, and damage of mucous membranes, which in consequence impairs absorption of the other components of the diet (Leszczyńska et al., 2007; Sochacka-Tatara et al., 2008).

The deficiencies observed may have resulted from food preferences of the children as well as from an uncritical imposition of adult dietary habits upon the children.

Szczepaniak et al. (2002) observed that children like meat and cured meat products, especially ham, loin, and sausages, whereas those meat products that contain visible fat in places belong to those disliked. Also the children studied preferred lean meat products; however, these did not occur in the diet in sufficient amounts, which is reflected by iron deficiencies. It also became apparent during the study that the children generally disliked dairy products served in the schools. These were usually in the form of milk and milk drinks, as well as rennet cheeses. This corresponds to the results reported by Kozlowska- Wojciechowska and Makarewicz-Wujec (2005). Also Kolarzyk et al. (2008) observed that milk is the least preferable dairy product within the group of preschool children.

The results of the survey suggest that the children selected their preferable food items from those served in the pre-school. Moreover, the parents prepared home meals according to the preferences of their children rather than in conformity with dietary recommendations. A report by the Public Opinion Research Center (Zwyczaje, 2006) demonstrates that nearly 60\% of respondents share the opinion that it is important that a child receives its preferable food items and likes the meal.

In both rural and urban areas (boys and girls) none of the diets were deficient in terms of vitamins B2 and B6. Deficiencies of other vitamins affected a very small number of children. In this context, it should be reconsidered whether healthy children should receive so commonly applied supplements of vitamins and fish-liver oil, the latter containingbesides unsaturated fatty acids-considerable amounts of vitamin $\mathrm{A}$.

\section{REFERENCES}

Abdel-Rahman, T.A., N.N. Kamal, K.H.A. ElDessouki and A.A. AbdAllah (2017). Assessment of nutritional status and Cognitive Development of Preschool Children at Minia Governorate, Egypt. The Canadian J. Clinical Nutr., 5 (1): 72-94.

Charzewska, J. and H. Weker (2006). Nation wide research on calcium and vitamin D content in diets of four-year old children. Pediat. Współ. Gastroenterolog. Hepat. Żyw. Dziecka, 8 (2): 107 -109.

Ciborowska, H. and A. Rudnicka (2007). Dietetics. Nutrition of the healthy and diseased person. Wyd. Lek. PZWL Warszawa. 
Dolla, C.K., P. Meshram, P. Shrivastava, C. Karjarma, S. Das and M. Uike (2005). Nutritional status of kodaku pre-school children in central India. J. Hum. Ecol., 17 (3): 229-231.

Dominick, S. and R. Derrick (2001). Theory and problems of statistics and econometrics, $2^{\text {nd }}$ Ed., New York, USA, 202-220.

Food Composition (1996). Tables for Egypt. Nutr. Inst., ARE, 115.

Friedrich, M. and M. Rukojć (2001). Assessment of vegetarian and traditional diets and the nutritional status of children aged 1-3. Żywność 28 (3 supl.), 42-52.

Gawęcki, J., G. Galiński, M. Konieczka and M. Kufel (2005). The quantitative and qualitative estimation of the consumption of fats and carbohydrates by pre-school children from different environments and regions. Now. Lek., 74 (4): 393-395.

Gronowska-Senger, A. (2007). Nutrition, life style and health of the Poles. Żyw. Człow. Metab., 34 (1/2): 12-21.

Grover, K., I. Singh and R. Jain (2009). Anthropometric profile of rural pre-school children belonging to different agroclimatic regions of punjab. Anthropologist, 11 (1): 25-30.

Hanumantha, R.D., R.K. Malliknarjuna, G. Radhaiah and R.N.P. Prahlad (1994). Nutritional status of tribal Pre-school children in three ecological zones of Madhya Pradesh. Indian Pediatr, 31: 635-640.

Kleeman, C.R., J. Bohannan, D. Bernstein, S. Ling and M.H. Maxwell (1964). Effect of variations in sodium intake on calcium excretion in normal humans. Proc. Soc. Exp. Biol. Med., 115 : 29-32.

Kolarzyk, E., A. Janik and J. Kwiatkowski (2008). Nutritional habits of pre-school children. Probl. Hig. Epidemiol., 89 (4): $527-$ 532.

Kozłowska-Wojciechowska, M. and M. Makarewicz-Wujec (2005). Nutritional behavior of pre-school children. Rocz. PZH, 56 (2): 165-169 .
Leszczyńska, T., E. Sikora, K. Kręcina and K. Pysz (2007). Meals served in nursery schools and their share in meeting the recommended daily demand for energy and nutrients exemplified by one selected canteen. Żywn. Nauka Techn. Jakość, 55 (6): 327-334.

Nanda, S. (2000). Assessment of an improved module of national adolescent girls scheme and evaluation of ongoing scheme. Ph.D. Dissertation (Unpublished), Chandigarh: Punjab Univ.

Nordin, B.E.C. and K.J. Policy (1987). Metabolic consequences of the menopause. A crosssectional, longitudinal and intervention study on 557 normal postmenopausal women. Calcif. Tiss. Int., 41: 1-60.

Nutrition (2004). Vitamin and mineral status: effects on physical performance. Jul.-Aug., 20 (7-8): 632-644.

O'dea, J.A. (2003). Why do kids eat healthful food? Perceived benefits of and barriers to healthful eating and physical activity among children and adolescents. J. Ame. Diet. Assoc., 103 (4) : 497-501.

Ołtarzewski, M., L. Szponar and E. Rychlik (2003). Calcium consumption among children and teenagers in Poland. Żyw. Człow. Metab., $30(1 / 2): 278-283$.

Pudło, E., R. Bednarski, T. Nierebiński and T. Dawidowicz (2000). The estimation of children nutrition in military pre-schools, on the ground of the laboratory analysis of dinner- meals and the theoretical calculation of decadal food-storage reports. Żyw. Człow. Metab., 27 (Supl.): 172-175.

Sadowsk, J., M. Radziszewska and A. Krzymuska (2010). Evaluation of nutrition manner and nutritional status of pre-school children. Acta Sci. Pol., Technol. Aliment., 9 (1): 105-115.

Saluja, N., S. Garg and H. Chopra (2011). Prevalence of morbidity and morbidity pattern in school children (5-11 years) in Urban area of Meerut. Int. J. Epidemiol., 2:2.

Shaikh, M.K., N. Kamble, D. Bhawnani, S. Bele and S.R. Rao (2016). Assessment of nutritional status among school children of 
Karimnagar, Telangana, India. Int. J. Res. Med. Sci., 4 (10): 4611-4617.

Sochacka-Tatara, E., R. Jacek, A. Sowa and A. Musiał (2008). Assessment of preschool children's diet. Probl. Hig. Epidemiol., 89 (3): 389-394 .

Szczepaniak, B., D. Górecka and A. JędrusekGolińska (2002). Nutritional preferences among children at pre-school age. Acta Sci. Pol., Technol. Aliment., 1:101-107.

Szponar, L., M. Ołtarzewski and E. Rychlik (2003). Energy and proteins in daily food of different population groups in Poland. Żyw. Człow. Metab., 30 (1/2): 113-119 .
Walter, T. (1994). Effect of iron-deficiency anaemia on cognitive skills in infancy and childhood. Baill. Clin. Haematol., 7:815-827.

Weatherholtz, W.M., T.C. Campbell and R. Webb (1969). Effect of dietary protein levels on the toxicity and metabolism of heptachlor. J. Nutr., 98 : 90-96.

WHO (1999). World Health Organization International Society of Hypertension. Procedure in the arterial hypertension. Current (1999) guidelines. Med. Prakt., 5 (9): 15-63.

Zwyczaje (2006). Nutritional manner of Poles. Results of public opinion poll. Centrum Badania Opinii Społecznej Warszawa.

\section{تقبيــم الحسـالة الغـذائيسـة لأطفــال الحضــــــة بمحسفظـة الشـرقيـة

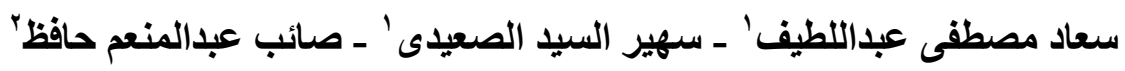

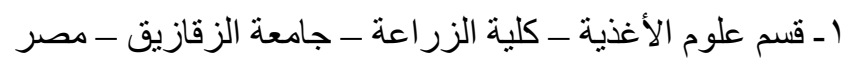

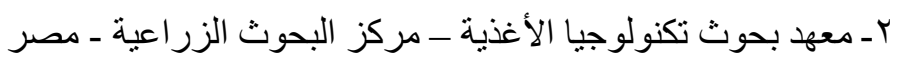

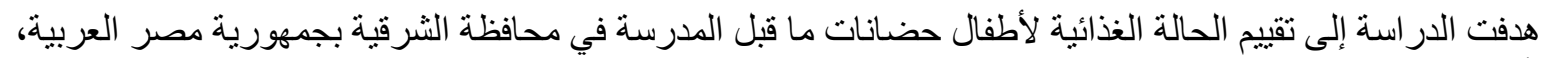

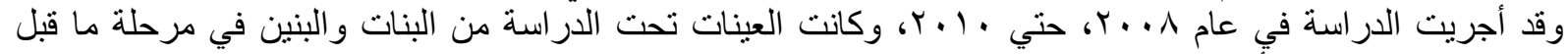

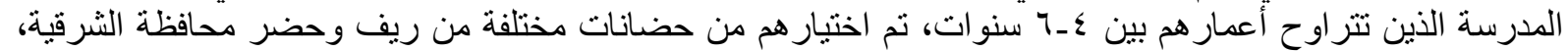

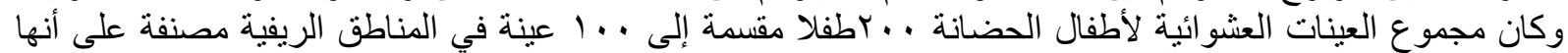

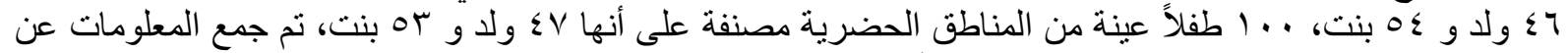

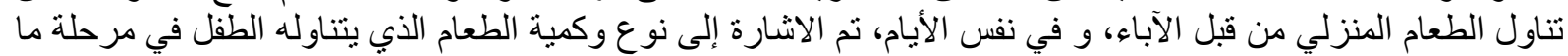

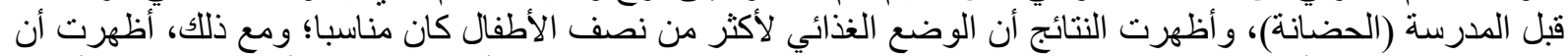

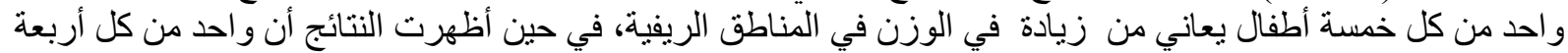

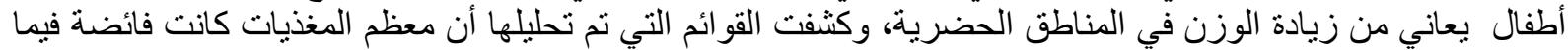

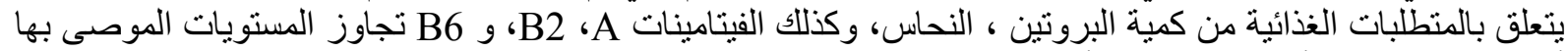

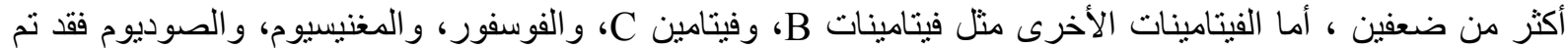

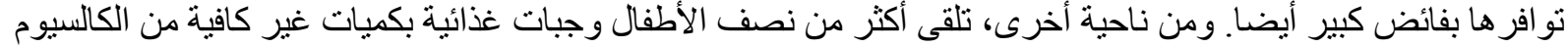

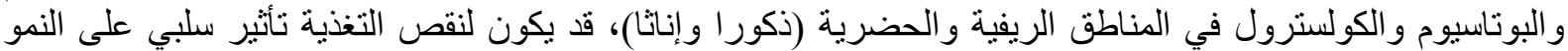
البدني و العقلي للأطفال وقد يزيد من خطر الإصابة بالأمر اض في حياتهم المستقبلية للبالغين. 